
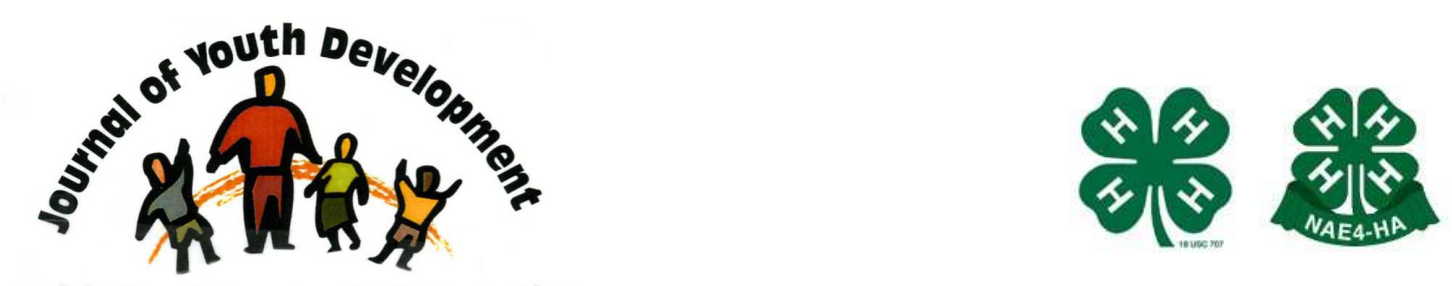

Bridging Research \& Practice

\title{
Toward a Theory-Predicated Definition of Digital Literacy for Early Childhood
}

\author{
Elizabeth R. Kazakoff \\ Eliot-Pearson Department of Child Development \\ Tufts University \\ Medford, MA \\ Elizabeth.Kazakoff@tufts.edu
}




\title{
JOURNAL OF YOUTH DEVELOPMENT \\ bridging research and practice

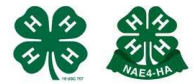

Volume 9, Number 1, Special Edition 2014

Article 140901FA003

\section{Toward a Theory-Predicated Definition of Digital Literacy for Early Childhood}

\author{
Elizabeth R. Kazakoff \\ Tufts University
}

\begin{abstract}
Though young children are frequent users of digital technology, there is no comprehensive definition of early childhood digital literacy. Currently, digital literacy and related terms are defined with much older children and adults in mind. This paper aims to lay groundwork for redefining digital literacy in an early childhood context. Taking into account the unique developmental needs of early childhood when discussing digital literacy can provide a gateway to developing technological tools and curricula to prepare children in kindergarten through second grade to be more effective users of digital technologies throughout their lives.
\end{abstract}

\section{Introduction}

Young children are frequent technology users. According to a Common Sense Media Study (2011), over half of two to four year olds and $90 \%$ of five to eight year olds have used a computer, and a-over quarter of children under age eight have used a mobile device (e.g., cell phone, tablet, etc.). Yet in the early grades, young children learn little in school about the digital tools that are part of their everyday lives (Bers, 2008). As such, the term digital literacy and related terms, such as new literacies, media literacy, and computer literacy (Coiro, Knobel, Lankshear, \& Leu, 2008), tend to be defined and analyzed with older children in mind (Lankshear, \& Knobel, 2003; Marsh, 2005).

According to the National Association for the Education of Young Children (NAEYC) Technology Policy Statement, "digital literacy is essential to guiding early childhood educators and parents in the selection, use, integration, and evaluation of technology and interactive media (NAEYC \& Fred Rogers Center, 2012, p. 9)." This statement, while reflecting the importance of digital literacy for educators and parents, does not outline what digital literacy means for the young children in their care. This paper aims to consider early child development theory, and current digital literacy definitions and frameworks, in order to answer the question: what does digital literacy mean in early childhood? 


\section{Background}

\section{Digital Technology Use in Early Childhood}

For many young children, digital devices are common. A majority of homes in the U.S.A. have a computer (81\%). Daily, half of children (53\%) under six use a computer at home and over half of children two to four years old (53\%) have used a computer with average age of first computer use at three-and-a-half years old (Common Sense Media, 2011).

Digital technology use is not universal, however, and varies with income. Around $48 \%$ of families who earn less than $\$ 30,000$ a year own a computer compared to $91 \%$ of families who earn over $\$ 75,000$ per year (Common Sense Media, 2011). In addition, $10 \%$ of lower-income parents own a smart device versus $34 \%$ of upper-income families, and $2 \%$ of lower income families have a tablet computer versus $17 \%$ of upper-income families. Over a third (38\%) of lower-income parents did not know what an "app" was (mobile application), compared with 3\% of higher-income parents (Common Sense Media, 2011).

Research indicates that simply providing access to technology for children is not enough to generate an understanding of technology alone and it is important to understand the social context in which the technology is being used (Palfrey, \& Gasser, 2008; Zillien, \& Hargittai, 2009). Thus, schools likely play a key role as a place to learn about new technologies for children.

\section{Educational Policy}

For decades, early childhood curricula have focused primarily on literacy and math, especially with the educational reforms of No Child Left Behind (Zigler, \& Bishop-Josef, 2006). However, there has been some recent attention to STEM disciplines in early childhood (Gelman, \& Brenneman, 2004; Sesame Workshop, 2009; White House, 2013). Educational reform across organizations is now addressing technology frameworks for early childhood (see Barron, et. al., 2011; ISTE, 2007; NAEYC \& Fred Rogers, 2012; U.S. DOE 2010).

The U.S. government issued a series of reports, recommendations, and educational reforms around the use of technology in classrooms, with a focus on STEM education in grades $\mathrm{K}-12$, based on increased attention to the United States lagging far behind other countries in STEM areas (Chiong, \& Shuler, 2010; PISA, 2006). According to the National Education Technology Plan, a government report on technology and education, computer technology must be used in classrooms to provide relevant learning environments and assessment tools for children (U.S. DOE, 2010). Furthermore, citing the 2006 Programme for International Student Assessment results (PISA, 2006), the Educate to Innovate campaign encourages participation in STEM areas by establishing partnerships between the federal government, nonprofits, and corporations. PISA reported American students lag far behind other developed countries in math and science, ranking $25^{\text {th }}$ out of 30 in math and $21^{\text {st }}$ out of 30 in science (U.S. Congress Joint Economic Committee, 2012). While Educate to Innovate addresses K-12 education overall, one of several participating organizations specifically aimed at early childhood is Sesame Street, which adopted a STEM focus for its $40^{\text {th }}$ and $41^{\text {st }}$ seasons (Sesame Workshop, 2009).

Two early childhood focused organizations, the National Association for the Education of Young Children and the Fred Rogers Center, authored a technology policy statement which addresses several recommendations specifically related to the digital needs of children aged 3 to 8 years, including the need for educators to be able to understand, evaluate, and integrate 
developmentally appropriate technological devices for their classrooms (Barron, et. al., 2011; NAEYC \& Fred Rogers, 2012).

The Digital Age Teacher Preparation Council, a partnership between the Joan Ganz Cooney Center and Stanford Educational Leadership Institute, developed a blueprint for bringing developmentally appropriate educational technology tools and curricula into the classroom. Their report, Taking a Giant Leap, argues that implementing emergent technology tools, combined with ongoing professional development for teachers of children ages 3-8, may be a cost-effective way to implement new policies into schools, while addressing the new common core standards, improving assessments efficiency, keeping track of accountability of student achievement, creating incentives and plans for teacher and professional development, and providing access to public media (Barron, et. al, 2011).

The above sections briefly summarized the current state of policies related to young children and technology education. The next section will introduce key conceptual and theoretical issues for early childhood development as they relate to learning about new technologies. A section reviewing the current literature pertaining to digital literacy will follow that discussion.

\section{Conceptual and Theoretical Considerations}

The following sections discuss key theoretical and conceptual issues pertinent to early childhood development that inform the concept of digital literacy.

\section{Social-Cultural Dimensions}

Technology is created by the culture in which the child lives. Younger children do not provide themselves with the digital media in their lives; parents, families, and schools are the ones to make the purchases or hand the child the tools (Gutnick, Robb, Takeuchi, \& Kotler, 2010).

Digital technology has the potential to make learning more social, collaborative, and networked (Gee, 2010a; Jenkins, 2006). Researchers have found that, when children work at a computer, they speak twice as many words per minute than when engaged in other non-technology related play activities such as play dough and building blocks (New, \& Cochran, 2007) and they speak to their peers nine times more than when working on traditional puzzles (Muller, \& Perlmutter, 1985). Children, when working on computers, are also more likely to ask other children for advice and help, even if an adult is present, thus increasing child-child socialization (Wartella, \& Jennings, 2000). Even in situations where each child has an individual computer or his or her own piece of digital equipment to work with, children still choose to form groups (Druin, 1998).

In addition, literacy is a social-cultural phenomenon. Literacy, both traditional and digital, is a way in which people participate in their social and cultural groups (Gee, 2010b). New Literacy Studies (NLS) focuses on the study of literacy in a social, cultural, and historical context. It takes a holistic approach to understanding reading and writing as not just a cognitive achievement (Gee, 2010a). Gee (2008) also argues the disparity between tiers of language (e.g., everyday language vs. academic language) in traditional language is also found in digital literacy. Young children come to school with varying levels of both vocabulary, in the traditional view of early literacy (Hart, \& Risley, 1995) and now also with varying levels of digital literacy skills. As such, digital literacy should be taught along with traditional literacy skills to help bridge the digital divide and digital participation gap. 


\section{Social-Emotional Dimensions}

Technology is often used as a tool for self-expression. Computers can be programmed so they can be anything to anyone, taking on a "thousand forms" for a "thousand functions" and appealing to a "thousand tastes (Papert, 1980)." This view reflects the power of digital technology as an expressive tool. Even basic computer programs afford children the opportunity to draw and manipulate objects and pictures.

Information, communication, and digital technologies can elicit creativity (Berson, \& Berson, 2010). Children may use digital still and video cameras to create or play movies, take and share photographs, and use any one of the myriad of online programs or smart phone apps to edit and play with these files (Diakopoulous, et al., 2007; Jenkins, 2006; Palfrey, \& Gasser, 2008). With tablets, mp3 players, and traditional computers, children can make their own music or play music for dancing or singing. Furthermore, by combining recyclables and traditional art materials with technological components, young children can take a robotic base and turn it into anything they want, from a monster truck to a kitten to a flower for an interactive garden (Bers, 2008; Bers, et al., 2002; Rusk, et al., 2008).

Digital technologies, such as computers, can also be useful for social-emotional development. Computers allow for collaboration via email, Skype, and video conferencing with other classrooms; social interactions are enabled that were previously not possible due to physical location (NAEYC \& Fred Rogers, 2012).

For young children who are in a developmental process of learning how to work with others, the design features of the technology might promote social development. The classic developmental theorists, such as Piaget (1928) and Vygotsky (1978), discussed the influence of children on one another in order to develop cognitive and social skills. Collaboration with other children while using technology might help to foster interactions between peers who may otherwise be focused on their own thoughts (egocentrism) and might also engage in partnerships that expand the child's zone of proximal development (Vygotsky, 1978). Research shows that there is more spontaneous peer teaching and helping at a computer screen than during other classroom activities (Clements, \& Nastasi, 1992). For example, a child who is better skilled at using the mouse or browsing the web might work together with a child who had less exposure to it. A child who has used a digital camera at home, might show another child which button to press. Children may show each other their favorite smartphone apps and instruct each other on initial play instructions or create their own off-screen games to mimic those found on-screen.

\section{Cognitive Dimensions}

Seymour Papert (1980) developed the theory of constructionism based on Piaget's theory of constructivism. Papert replaced the " $v$ " of "constructi vism" with the " $t$ " to stress the importance of constructions in the world. He focused on learning by making, most specifically on the computer screen, to support the construction of knowledge.

Both use of general computer applications and use of early computer programming languages has shown positive impact on cognitive abilities such as abstraction, problem solving, and structural knowledge (Clements, \& Sarama, 2002; Haugland, 1992; Wang, \& Ching, 2003). A review of early work in the field suggests that children who participated in computer programming activities typically scored around sixteen points higher on various cognitive-ability assessments compared to children who had not (Liao, \& Bright, 1991). The computer programming language, Logo, in a supportive classroom environment, has been found to 
impact a wide range of cognitive skills in early childhood, including meta-cognition (Clements, 1986; Miller, \& Emilhovich, 1986), transfer of skills in problem representation, problem solving, and debugging (Degelman, Free, Scarlato, Blackburn, \& Golden, 1986; Klahr, \& Carver, 1988; Salomon, \& Perkins, 1987).

More recently, computer programming in early childhood has also shown a positive impact on sequencing skills (Kazakoff, \& Bers, 2012; Kazakoff, Sullivan, \& Bers, 2013) and powerful computational ideas, such as understanding control flow, and loops and branches (Bers, et al., 2002; Bers, 2008; Bers, 2010; Bers, \& Horn, 2010). New research on innovative computer programming environments supports the argument that children's programming of animations, graphical models, games, and robots with age-appropriate materials allow children to learn and apply core computational thinking concepts such as abstraction, automation, analysis, decomposition, and iterative design (e.g., Lee, et al., 2011; Mioduser, \& Levy 2010; Mioduser, Levy, \& Talis, 2009; Resnick, 2006; Resnick, et al., 2009). Finally, research on newer technologies tools, such as cell phone apps, may have a positive impact on vocabulary and literacy skills in three to seven year olds (Chiong, \& Shuler, 2010).

\section{Relational Developmental Systems}

As the above discussions of individual dimensions demonstrate, it is difficult to describe technology and child development within the context of one area of developmental theory alone. Every component of a child's world is interconnected. Relational developmental systems theory takes these connections into account by rejecting all splits between person and context, and by addressing the child and his or her environment as an integrated whole, including all influences on developmental simultaneously - the biological, cultural, historical, etc. (Overton, 2010; Overton, \& Mueller, 2012). As such, the individual-context relation is the primary unit of analysis when studying human development from the relational developmental systems perspective (Lerner, 2002).

Accordingly, there are five key, interrelated questions developmental scientists may ask themselves when studying development from the relational developmental systems perspective that are particularly applicable to studying childhood development with technology. They are (Jelicic, Theokas, Phelps, \& Lerner, 2007): "(1) What attributes of (2) what individuals? In relation to (3) what contextual/ecological conditions?; at (4) what point in time?; may be integrated to promote (5) what instances of positive human development (p. 10)?" (emphasis added). These questions provide a relevant lens through which to view the intersection of children's development and technology. In other words, what developmental and personal attributes of young children, in the context of both home and school, promote positive child development using new technology?

The following section will explore this question by introducing a theoretical framework, Positive Technological Development (PTD) (Bers, 2007; 2012), for understanding technology use from a relational developmental systems and Positive Technological Development (PTD) (Bers, 2007; 2012) perspective and then by linking PTD with a cognitive-focused digital literacy framework. Both frameworks will be merged and adapted for use in understanding digital literacy in early childhood.

\section{Positive Technological Development}

The Positive Technological Development framework (PTD) combined the Positive Youth Development (PYD) perspective (Lerner, et al., 2005) with Papert's (1980) constructionism (Bers, 2007). The core questions of PTD ask "How can children use technology in positive ways 
to help themselves and the world?" and "How can educators and researchers develop programs that help children use technology to learn new things, to express themselves in creative ways, to communicate effectively, to take care of themselves and each other, and to contribute in positive ways to the self and the world" (Bers, 2007; 2012).

PTD emphasizes the developmental aspects of PYD' six " $C$ 's" framework: caring, connection, contribution, competence, confidence, and character (Bers, 2012; Lerner, et al., 2005) and connects these " $C$ 's" to corresponding action-oriented " $C$ ' $s$ " that can be integrated into the use of new technologies: communication, collaboration, community-building, content-creation, creativity, and conduct (Bers, 2007; 2012).

The PTD framework forms a basis for defining digital literacy for early childhood, since it is a comprehensive description of how technology is used across childhood and adolescence, and takes into consideration multiple developmental dimensions, including the personal, social, and emotional. Although it provides a way to frame the discussion from a developmental systems theory perspective, PTD does not directly address the age-specific issues of digital literacy in early childhood. The core of this paper will focus on merging PTD with current definitions of digital literacy, described in the next section, and discussing the unique needs of early childhood

\section{Current Discussion of Digital Literacy}

Digital literacy is a frequently used term, but it does not have a well-agreed upon definition. According to Aviram and Eshet-Alkalai (2006) "the discourse on this important subject has been practice-oriented, and lacks a sound integrative framework and theoretical foundation (n.p.)." In addition, the subject matter - digital technologies - are constantly changing.

The term digital literacy was, by many accounts, originally defined by Paul Gilster (1997) as "the ability to understand and use information in multiple formats from a wide range of sources when it is presented via computers (p. 1)." Of course, the technological world has changed dramatically since 1997, and we are no longer referring to only computers or the presentation of information when we discuss digital literacy. Content creation, would also have to be included in contemporary definition of digital literacy. Digital literacy more recently been defined as "a set of habits through which children use computer technology for learning, work, socializing, and fun (Ba, Tally, Tsikalas, 2002, p.1)." Again, this defintion focuses on computer use, not the breathe of digital tools avaialable, but moves towards integrating more childoriented motivations for use. James Paul Gee (2010b) described digital literacy as "different ways of using digital tools within different sorts of sociocultural practicies (p. 172)." This defintion encompasses more than just the computer as a tool and gives a social-cultural context to the behaviors children engage in when using digital technologies.

The term digital literacy occasionally appears under the umbrella of "New Literacies." The term "new literacy studies" has been used to describe a discipline for studying new types of literacy, beyond reading and writing, in the context of popular culture (Gee, 2010a). New literacies, however, are defined in different ways by different people (Leu, 2010) and, similar to the term digital literacy, new literacies also lack concise and consistent definitions, which hold researchers back in their discussions and research around new literacies - what they are, what they mean, their impact, and the tools children need for success (Leu, 2010). 
In cases where the terms are defined, the definitions and examples have little to no bearing on early childhood. A New Literacies Sampler begins by pointing out "typical" examples of new literacies: "video gaming, fan fiction writing, weblogging, using websites, and social practices involved in mobile computing" (Knobel, \& Lankshear, 2007). These examples have limited applicability to early childhood.

At the national policy level, the National Broadband Plan (FCC, 2010) notes that the same definition of digital literacy does not apply to children and adults, and goes on to describes activities that are applicable mainly to adults, older children, and adolescents. A U.S. government website has been developed for digital literacy training (http://digitalliteracy.gov) and most resources are targeted at adults, with only five resources categorized for under the age of thirteen.

Internationally, there is also focus on developing a universal digital literacy for framework for all citizens. The Institute for Prospective Technological Studies (IPTS) of the European Commission's Joint Research Centre (JRC) has embarked on a project to synthesis fifteen existing digital literacy frameworks, called DIGCOMP (Ferrari, 2012).

Eshet-Alkalai and collegues (Aviram, \& Eshet-Alkalai, 2006; Eshet-Alkalai, 2004; Eshet, 2005) created a model of digital literacy that encompasses cognitive in addition to functional skills. This model is based on six skills (Aviram, \& Eshet-Alkalai, 2006):

- Photo-Visual Literacy - ability to understand graphically presented information such as symbols, icons, and graphical user interfaces:

- Reproduction Literacy - the combination of existing media to create new media;

- Branching Literacy - ability to navigate hypermedia; navigation of digital media is nonlinear, branching requires good spatial skills to navigate information across many different pathways and not get "lost" in cyberspace;

- Information Literacy - the use of critical thinking skills to decipher false, biased, and/or irrelevant information;

- Socio-Emotional Literacy - communication and collaboration skills in an online environment;

- Real-Time Thinking Skills - ability to process and evaluate information in real-time (was later added to the framework and not present in the earlier literature (Eshet-Alkalai \& Chajut, 2009)).

Eshet-Alkalai's framework (Aviram, \& Eshet-Alkalai, 2006; Eshet-Alkalai, 2004; Eshet-Alkalai, \& Chajut, 2009) is also not, on its own, an ideal model for digital literacy for early childhood.

Research studies grounding this framework were conducted on adolescents and adults (EshetAlkalai, \& Chajut, 2010).

The following proposed framework is an initial step toward synthesizing an understanding a view of digital literacy in early childhood that is informed by the major theories of early childhood development theory. The six areas of the framework are intended to be technologyneutral, even when specific technologies are used as illustrative examples.

\section{Proposed Digital Literacy Framework for Early Childhood}

This framework of digital literacy for early childhood proposes a combination of Marina Bers' Positive Technological Development framework (Bers, 2007; 2010; 2012) and Yoram Eshet- 
Alkalai and colleague's Conceptual Model of Digital Literacy (Aviram, \& Eshet-Alkalai, 2006; Eshet-Alkalai, 2004; Eshet-Alkalai, \& Chajut, 2009), as viewed through an early childhood development lens. Although the Positive Technological Development framework has been applied across age groups, early childhood is not the specific focus of the framework. The two perspectives address themes that can be relevant to early childhood (i.e., understanding symbols, creativity, collaboration, building a sense of community, social-emotional development etc.). The proposed framework aims to unify these two perspectives while considering young children as producers, not only consumers, of digital technologies.

Bers' Positive Technological Development perspective focuses primarily on the personal, social, ethical and cultural aspects of technology use and Eshet-Alkalai's model focuses primarily on the cognitive aspects of technology use, thus, when combined, these two perspectives yield a relatively comprehensive view of technology use. Missing from these two perspectives are considerations specific to areas of interest for early childhood development namely motor, early literacy, and self-regulation skills. For example, Eshet-Alkali defines "Real-Time Thinking Skills" as processing large volumes of information in chat-rooms or computer games (Eshet-Alkalai, \& Chajut, 2009). This concept must be redefined for early childhood, as children under eight will likely not be using chat-rooms with dozens of conversations, for example. Instead, "Real-Time Thinking Skills," as previously mentioned, can be thought of in terms of children's different levels of executive function and their ability to process multiple, simultaneous inputs (see Diamond, \& Lee, 2011 for an overview).

Children aged two to eight have a wide range of abilities. Based on Bers', Eshet-Alkali's, and early childhood development perspectives, it can be proposed digital literacy in early childhood is about working towards building an understanding and fluency in the following areas:

- Interface Comprehension and Utilization

- Non-Linear Navigation

- Critical Thinking and Problem-Solving Skills involving Digital Domains

- Cooperative Learning and Play Afforded by Digital Tools

- Creative Design Afforded by Digital Tools

- Digitally Enhanced Communications

In addition, all six of these areas of understanding, and the child's abilities within each domain, are moderated by their individual learning and development trajectories, particularly "real-time thinking skills" or, what early childhood educators would generally think of as executive function. The table below outlines how prior theory, models, and perspective informed the categorization and definition of these six categories. 
Table 1

Proposed Facets of Digital Literacy in Early Childhood and Influencing Factors

\begin{tabular}{|c|c|c|}
\hline $\begin{array}{l}\text { Digital Literacy in Early } \\
\text { Childhood }\end{array}$ & Related Developmental Areas & Influencing Perspectives \\
\hline $\begin{array}{l}\text { Understanding \& Utilizing } \\
\text { Digital Interfaces }\end{array}$ & $\begin{array}{l}\text { Symbol Understanding } \\
\text { Fine Motor Skills } \\
\text { Hand-Eye Coordination } \\
\text { Linguistic } \\
\text { Social-Emotional } \\
\text { Social-Cultural }\end{array}$ & $\begin{array}{l}\text { Bers's Content Creation - engage users in } \\
\text { applications that work with text, video, audio, } \\
\text { graphics, and animations } \\
\text { Eshet-Alkali's Photo-Visual Literacy- ability to work } \\
\text { effectively with digital environments, such as user } \\
\text { interfaces, that employ graphical communication. }\end{array}$ \\
\hline Non-Linear Navigation & $\begin{array}{l}\text { Cognitive } \\
\text { Symbol Understanding } \\
\text { Linguistic }\end{array}$ & $\begin{array}{l}\text { Eshet-Alkali's Branching Literacy-ability to construct } \\
\text { knowledge by nonlinear navigation of the Internet } \\
\text { and other hypermedia }\end{array}$ \\
\hline $\begin{array}{l}\text { Critical- Thinking and } \\
\text { Problem-Solving Skills in } \\
\text { Digital Domains }\end{array}$ & $\begin{array}{c}\text { Cognitive } \\
\text { Social-Emotional }\end{array}$ & $\begin{array}{l}\text { Eshet-Alkali's Information Literacy - ability to } \\
\text { consume information critically and sort out false and } \\
\text { biased information }\end{array}$ \\
\hline $\begin{array}{l}\text { Cooperative Learning and } \\
\text { Play Afforded by Digital } \\
\text { Tools in Early Childhood }\end{array}$ & $\begin{array}{l}\text { Social-Emotional } \\
\text { Social-Cultural }\end{array}$ & $\begin{array}{l}\text { Bers's Collaboration - working with others and willing } \\
\text { to cooperate toward a shared task } \\
\text { Bers's Community Building - using technology to } \\
\text { enhance the community and the quality of } \\
\text { relationships among the people of that community; } \\
\text { contribute to society by using and inventing new } \\
\text { digital tools to solve social problems } \\
\text { Bers's Communication - exchanging thoughts, } \\
\text { opinions, or information by using technologies } \\
\text { Eshet-Alkali's - Social-Emotional Literacy - ability to } \\
\text { communicate effectively in online communication } \\
\text { platforms }\end{array}$ \\
\hline $\begin{array}{l}\text { Creative Design Afforded by } \\
\text { Digital Tools in Early } \\
\text { Childhood }\end{array}$ & $\begin{array}{l}\text { Social-Emotional } \\
\text { Social-Cultural } \\
\text { Fine-Motor Skills }\end{array}$ & $\begin{array}{l}\text { Eshet-Alkali's Reproductive Literacy- } \\
\text { ability to create new artwork by reproducing and } \\
\text { manipulating preexisting digital text, visual, or audio } \\
\text { pieces } \\
\text { Bers's Content Creation - engage users in } \\
\text { applications that work with text, video, audio, } \\
\text { graphics, and animation } \\
\text { Bers's Creativity - ability to create and imagine } \\
\text { original new ideas, forms, and methods for using new } \\
\text { technologies }\end{array}$ \\
\hline $\begin{array}{l}\text { Digitally Enhanced } \\
\text { Communications in Early } \\
\text { Childhood }\end{array}$ & $\begin{array}{l}\text { Social-Emotional } \\
\text { Social-Cultural }\end{array}$ & $\begin{array}{l}\text { Bers's Collaboration - working with others and willing } \\
\text { to cooperate toward a shared task } \\
\text { Bers's Community Building - using technology to } \\
\text { enhance the community and the quality of } \\
\text { relationships among the people of that community; } \\
\text { contribute to society by using and inventing new } \\
\text { digital tools to solve social problems } \\
\text { Bers's Communication - exchanging thoughts, } \\
\text { opinions, or information by using technologies } \\
\text { Eshet-Alkali's Social-Emotional Literacy - ability to } \\
\text { communicate effectively in online communication } \\
\text { platforms }\end{array}$ \\
\hline
\end{tabular}


The six areas are defined as follows:

Understanding \& utilizing digital interfaces. Understanding and utilizing digital interfaces describes the ability to comprehend and use physical and graphical tools within digital devices, made possible by both hardware and software components. These would include touchscreen input, navigation with a mouse, and keyboard use as well as the recognition and use of symbols and icons corresponding to varying functions. For example, young children may be better able to use a touchscreen interface over a screen and mouse. Touching icons on a screen is a direct finger-to-action effect, compared to using a mouse, which involves looking at the screen, more advanced hand-eye coordination, and fine motor skills to control the mouse itself. This dimension of the digital literacy for early childhood framework is influenced by Bers's Content Creation - engage use in applications that work with text, video, audio, graphics, and animations and Eshet-Alkali Photo-Visual Literacy - ability to work effectively with digital environments, such as user interfaces, that employ graphical communication.

Non-Linear Navigation. Non-linear navigation is making sense of, and navigating through, non-linear text, icons, and activities. For example, young children encounter non-linear stories in e-books embedded with graphics, during the use of software tools, and when navigating websites. Non-linear navigation expands upon Eshet-Alkali's concept of branching literacy, the ability to navigate hypermedia and non-linear digital media. Eshet-Alkali expressed that nonlinear navigation requires spatial skills, however, when considering this concept for early childhood limited working memory and self-regulation skills must also be taken into account. For example, young children may not be able to remember beyond four steps of navigation or resist clicking on available links. In terms of software development, features like "auto-save" may be useful so that children do not lose their work if they navigate away from their work without remembering the steps to save.

Critical-thinking and problem-solving skills in digital domains. Critical-thinking and problem-solving skills in digital domains involve the ability to navigate new information and evaluate what is true and false as well as what is real and make-believe. This builds on EshetAlkali's idea of information literacy, the ability to consume information critically and sort out false and biased information.

For young children, who are not yet able to read information on the Internet, this concept is more relevant when understanding the difference between talking to relatives online versus in person, for example, or learning what to do if a "pop-up" add appears or if they are using a tablet app and are prompted for an in-app purchase. The ability to process information and decide what to do next becomes more important as children use digital tools independently. However, young children begin to recognize symbols as part of early literacy skills and, through digital technologies can also learn symbol navigation, such as an " $X$ " or an "OK" button, and when these buttons should and should not be pressed. In addition, educational technology tools have recently been developed specifically for young children to aid in development of problemsolving and critical thinking skills, including computer programming languages (e.g., ScratchJr, CHERP, Daisy the Dinosaur) and robotics tools (e.g., Bee-Bot, Lego WeDo).

Cooperative Learning and Play Afforded by Digital Tools in Early Childhood. Cooperative learning and play afforded by digital tools in early childhood builds on several aspects of Bers's PTD and Eshet-Alkali's frameworks. From Bers's, collaboration - working with others on a shared task; community-building - using technology to enhance the community and the quality of relationships among the people of that community and contribute to society by 
using and inventing new digital tools to solve social problems; communication - exchanging thoughts, opinions, or information by using technologies; and, from Eshet-Alkali, socialemotional literacy - ability to communicate effectively in online communication platforms.

For young children, cooperative learning and play is a foundational part of the PreK through second grade educational experience. Collaboration, community-building, and communication through technology can be an added layer to further enhance this key part of a young child's classroom experience. In addition, Eshet-Alkali notes the important of social-emotional literacy in online platforms. In early childhood, social-emotional development is a foundational skill learned both in school and at home.

To focus on a specific example, children may collaborate by sharing limited technological resources in the classroom. At home, children may participate in virtual communities (e.g., Club Penguin). At both home and school, young children may use digital communication and photo-sharing tools such to communicate with classrooms and family members around the world.

Creative Design Afforded by Digital Tools in Early Childhood. Creative design afforded by digital tools in early childhood is influenced by content-creation - users engaging with applications that use text, video, audio, graphics, animations, etc. and creativity - ability to create and imagine original new ideas, forms, and methods for using new technologies from Bers's framework with reproductive literacy - ability to create new work by reproducing and manipulating existing digital text, audio, or visual pieces from Eshet-Alkali's framework.

Creativity is also an essential part of early childhood. Digital technologies layer on another tool for creative design and self-expression. Young children may use digital tools to explore art tools and paint with not only color, but also patterns. They may also become users of digital and video cameras, bringing their own stories to life and documenting their experiences.

Digitally Enhanced Communications in Early Childhood. Digitally enhanced communications in early childhood refers to being able to use digital communication tools and understanding the affordances and potential disadvantages of digital-based communication methods. The digitally enhanced communications area is influenced by collaboration, community-building, and communication, from the PTD framework and social-emotional literacy, from Eshet-Alkali's framework.

As mentioned in the collaboration section, classrooms may now have a Twitter feed they share with other classrooms or their parents. Children and teachers can document their daily activities through audio and video recordings, which can also be uploaded to YouTube accounts or Wikis to share. These are just two examples of the increased access digitally enhanced communications allow, but also a cause for concern around privacy issues. Most online tools allow users to set privacy settings, but it is impossible to fully control how data is shared once it is on the Internet.

\section{Conclusion and Future Directions}

The framework of digital literacy for early childhood outlined above intends to contribute to our understanding of young children as producers, not just consumers, of digital content. The outlined components of the framework aim to combine cognitive, physical, social-emotional, and social-cultural elements in order to promote positive uses of technology, while taking into 
consideration the specific developmental needs of early childhood, such as fine motor skills, personal and social development, executive function skills and, emergent literacy.

With young children using digital technologies on a daily basis, existing definitions and frameworks of digital literacy - ones that assume digital technology users have fine motor skills, adequate reading ability, an understanding of cause and effect, and high levels of executive function - are not suitable definitions for young children. A clear definition of digital literacy for early childhood can provide a guideline for learning with and about digital technology for children ages two to eight. Many young children are using digital tools on a daily basis. Developmentally appropriate frameworks are necessary to ensure that children are taught what they need to know to be successful when they use these tools, and that new tools are developed with young children in mind.

\section{References}

Aviram, A., \& Eshet-Alkalai, Y. (2006). Towards a theory of digital literacy: Three scenarios for the next steps. European Journal of Open, Distance and E-Learning. Retrieved from http://www.eurodl.org/materials/contrib/2006/Aharon Aviram.htm.

Ba, H., Tally, W., \& Tsikalas, K. (2002). Investigating children's emerging digital literacies. Journal of Technology, Learning, and Assessment, 1(4), 1-49.

Barron, B., Cayton-Hodges, G., Bofferding, L., Copple, C., Darling-Hammond, L., Levine, M. (2011). Take a Giant Step: A Blueprint for Teaching Children in a Digital Age. New York: The Joan Ganz Cooney Center at Sesame Workshop.

Bers, M. (2012). Designing Digital Experiences for Positive Youth Development: From playpen to playground. New York, NY: Oxford University Press.

Bers, M., \& Horn, M. (2010). Tangible programming in early childhood: Revisiting developmental assumptions through new technologies. In I.R. Berson \& M.J. Berson (Eds.), High-tech tots: Childhood in a digital world (pp. 49-70). Greenwich, CT: Information Age Publishing.

Bers, M., Ponte, I., Juelich, K., Viera, A., \& Schenker, J. (2002). Teachers as Designers: Integrating Robotics into Early Childhood Education. Information Technology in Childhood Education, 1, 123-145.

Bers, M. (2007). Positive Technological Development: Working with computers, children, and the Internet. MassPsych, 51(1), 5-7, 18-19.

Bers, M.U. (2008). Blocks to Robots: Learning with technology in the early childhood classroom. New York: Teacher's College Press.

Bers, M.U. (2010). The TangibleK Robotics Program: Applied Computational Thinking for Young Children. Early Childhood Research and Practice, 12(2). 
Berson, I. R., \& Berson, M. J. (Eds.). (2010). High-tech tots: Childhood in a digital world. A Volume in I. R. Berson \& M. J. Berson (Series Eds.) Research in Global Child Advocacy. Charlotte, NC: Information Age Publishing.

Chiong, C., \& Shuler, C. (2010). Learning: Is there an app for that? New York, NY: The Joan Ganz Cooney Center at Sesame Workshop.

Clements, D.H., \& Nastasi, B.K. (1992). Computers and early childhood education. In Gettinger, M., Elliott, S.N., \& Kratochwill, T.R. (Eds.), Advances in school psychology: Preschool and early childhood treatment directions (pp. 187-246). Hillsdale, NJ: Lawrence Erlbaum Associates.

Clements, D.H., \& Sarama, J. (2002). The role of technology in early childhood learning. Teaching Children Mathematics, 8, 340-343.

Clements, D.H. (1986). Effects of Logo and CAI environments on cognition and creativity. Journal of Educational Psychology, 78, 309-318.

Coiro, J., Knobel, M., Lankshear, C., \& Leu, D.J. (Eds.) (2008). Handbook of Research on New Literacies. New York, NY: Lawrence Erlbaum Associates.

Common Sense Media. (2011). Zero to Eight: Children's Media Use in America. Retrieved from http://www.commonsensemedia.org/research/zero-eight-childrens-media-use-america.

Degelman, D., Free, J.U., Scariato, M., Blackburn, J.M., \& Goldent, T. (1986). Concept learning in preschool children: Effects of a short-term Logo experience. Journal of educational computing research, 2, 199-205.

Diakopoulous, N., Luther, K., Medynskiy, Y.E., \& Essa, I.A. (2007). Remixing Authorship: Reconfiguring the Author in Online Video Remix Culture. SIC Technical Reports; GIT-IC-07-05. Atlanta, GA: Georgia Institute of Technology.

Diamond, A., \& Lee, K. (2011). Interventions shown to aid executive function development in children 4 to 12 years old. Science, 333, 959 - 963. DOI: $10.1126 /$ science.1204529.

Druin, A. (1998). The Design of Children's Technology (Ch 2-3). San Francisco: Morgan Kaufmann.

Eshet-Alkalai, Y. (2004). Digital literacy: A conceptual framework for survival skills in the digital era. Journal of Educational Multimedia and Hypermedia, 13(1), 93-106.

Eshet, Y. (2005). Computers and Cognition: Cognitive Skills Employed in Digital Work. IADIS Virtual Multi Conference on Computer Science and Information Systems, 51-56.

Eshet-Alkalai, Y. (2004). Digital literacy: A conceptual framework for survival skills in the digital era. Journal of Educational Multimedia and Hypermedia, 13(1), 93-106.

Eshet-Alkalai, Y., \& Chajut, E. (2009). Changes over time in digital literacy. Cyberpsychology \& Behavior, 12(6), 713-715. 
Eshet-Alkalai, Y., \& Chajut, E. (2010). You can teach old dogs new tricks: The factors that affect changes over time in digital literacy. Journal of Information Technology Education, 9, 173-181.

FCC (2010). National Broadband Plan. Retrieved from http://www.broadband.gov/downloadplan/.

Ferrari, A. (2012). Digital Competence in Practice: An analysis of frameworks. Luxembourg: Publications Office of the European Union.

Gee, J.P. (2010a). New Digital Media and Learning as an Emerging Area and 'Worked Examples' as One Way Forward. Cambridge, MA: MIT Press.

Gee, J.P. (2010b). A situated-sociocultural approach to litearcy and technology. In E.A. Baker (Ed.) The New Literacies: Multiple perspectives on research and practice (pp. 165-189). New York, NY: The Guilford Press.

Gee, J.P. (2008). Getting Over the Slump: Innovation Strategies to Promote Children's Learning. New York, NY: The Joan Ganz Cooney Center at Sesame Workshop.

Gelman, R., \& Brenneman, K. (2004). Science learning pathways for young children Early Childhood Research Quarterly (Special Issue on Early Learning in Math and Science), 19(1), 150-158.

Gilster, P. (1997). Digital Literacy. New York, NY: John Wiley \& Sons, Inc.

Gutnick, A.L., Robb, M., Takeuchi, L., \& Kotler, J. (2010). Always connected: The new digital media habits of young children. New York: The Joan Ganz Cooney Center at Sesame Workshop.

Hart, B.M. \& Risley, T.R. (1995). Meaningful differences in the everyday experience of young American children. Baltimore, MD: Paul H. Brookes.

Haugland, S.W. (1992). The effect of computer software on preschool children's developmental gains. Journal of Computing in Childhood Education, 3(1), 15-30.

ISTE (International Society for Technology in Education). (2007). NETS for Students 2007 Profiles. Washington, DC: ISTE. Retrieved from www.iste.org/standards/nets-for-students/netsfor-students-2007-profiles.aspx\#PK-2.

Jelicic, H., Theokas, C., Phelps, E., \& Lerner, R.M. (2007). Conceptualizing and measuring the context within person $\leftarrow \rightarrow$ context models of human development: Implications for theory, research and application. In T.D. Little, J.A. Bovaird, \& N.A. Card (Eds.). Modeling contextual effects in longitudinal studies (437-456). Mahwah, NJ: Erlbaum.

Jenkins, H. (2006). Confronting the Challenges of Participatory Culture: Media Education for the $21^{\text {st }}$ Century. Chicago, IL: The John D. and Catherine T. MacArthur Foundation.

Kazakoff, E.R., \& Bers, M. (2012). Programming in a robotics context in the kindergarten classroom: The impact on sequencing skills. Journal of Educational Multimedia and Hypermedia, 21(4), 371-391. 
Kazakoff, E.R., Sullivan, A., \& Bers, M. (2013). The effect of a classroom-based intensive robotics and programming workshop on sequencing ability in early childhood. Early Childhood Education Journal. DOI: 10.1007/s10643-012-0554-5.

Klahr, D., \& Carver, S. (1988). Cognitive objectives in a LOGO debugging curriculum: Instruction, learning, and transfer. Cognitive Psychology 20, 362-404.

Knobel, M., \& Lankshear, C. (Eds). (2007). A New Literacies Sampler. New York, NY: Peter Lang Publishing.

Lankshear, C., \& Knobel, M. (2003). New Literacies: Changing Knowledge and Classroom Practice. Buckingham, UK: Open University Press.

Lee, I., Martin, F., Denner, J., Coulter, B., \& Allan, W., et al. (2011). Computational thinking for youth in practice. ACM Inroads, 2(1), 32-37.

Lerner, R.M. (2002). Concepts and theories of human development ( ${ }^{\text {rd }}$ ed.). Mahwah, NJ: Lawrence Erlbaum Associates.

Lerner, R., Lerner, J., Almerigi, J., Theokas, C., Phelps, E., Gestsdottir, S., et al. (2005). Positive youth development, participation in community youth development programs, and community contributions of fifth-grade adolescents: Findings from the first wave of the 4-H study of positive youth development. Journal of Early Adolescence, 25(1), 17-71.

Leu, D.J. (2010). Forward. In E.A. Baker (Ed.), The New Literacies: Multiple perspectives on research and practice (pp. vii $-\mathrm{xi}$ ). New York, NY: The Guilford Press.

Liao, Y-K., \& Bright, G. (1991). Effects of computer-assisted instruction and computer programming on cognitive outcomes: A meta-analysis. Journal of Educational Computing Research, 7, 251-268.

Marsh, J. (2005). Introduction: Children of the digital age. In J. Marsh (Ed.) Popular culture, new media, and digital litearcy in early childhood (pp. 1 - 10). New York, NY: Routledge Falmer.

Miller, G.E., \& Emilhovich, C. (1986). The effects of mediated programming instruction on preschool children's self-monitoring. Journal of Educational Computing Research, 2, 283-297.

Muller, A.A., \& Perlmutter, M. (1985). Preschool children's problem-solving interactions at computers and jigsaw puzzles. Journal of Applied Developmental Psychology, 6, 173 - 186.

Mioduser, D., \& Levy, S. (2010). Making sense by building sense: Kindergarten children's construction and understanding of adaptive robot behaviors. International Journal of Computers for Mathematical Learning 15(2), 99-127.

Mioduser, D., Levey, S., \& Talis, V. (2009). Episodes to scripts to rules: concrete-abstractions in kindergarten children's explanations of a robot's behaviors. International Journal of Technology and Design Education 19(1), 15-36. 
National Association for the Education of Young Children (NAEYC) \& Fred Rogers Center. (2012). Technology and Interactive Media as Tools in Early Childhood Programs Serving Children from Birth through Age 8. Retrieve from

http://wWw.naeyc.org/files/naeyc/file/positions/PS technology WEB2.pdf

New, R.S., \& Cochran, M. (Eds.) (2007). Early Childhood Education: An International Encyclopedia, Volume 3. Westport, CT: Prager Publishers.

Overton, W.F. (2010). Life-span development: Concepts and issues. In R.M.Lerner (Ed). Handbook of life-span development (pp. 1-29). Hoboken, NJ: Wiley.

Overton, W.F., \& Mueller, U. (2012). Chapter 2. Metatheories, theories, and concepts in the study of development. Handbook of Psychology In R.M. Lerner, M.A. Easterbrooks, \& J. Mistry (Eds.), Handbook of psychology: Vol. 6. Developmental psychology (2nd ed.), (pp. 19 - 58). Hoboken, NJ: Wiley.

Palfrey, J., \& Gasser, U. (2008). Born Digital: Understanding the First Generation of Digital Natives. New York, NY: Basic Books.

Papert, S. (1980). Mindstorms: Children, Computers and Powerful Ideas. New York: Basic Books.

Piaget, J. (1928). Judgment and reasoning in the child. London: Routledge \& Kegan Paul.

Programme for International Student Assessment (PISA). (2006). The Pisa International Database. Retrieved from http://pisa2006.acer.edu.au/

Resnick, M. (2006). Computer as paintbrush: Technology, play, and the creative society. In D. Singer, R. Golikoff, \& K. Hirsh-Pasek (Eds.), Play = learning: How play motivates and enhances children's cognitive and social-emotional growth. New York, NY: Oxford University Press.

Resnick, M., Maloney, J., Monroy-Hernandez, A., Rusk, N., Eastmond, E., Brennan, K., Kafai, Y. (2009). Scratch: Programming for All. Communications of the ACM, 52(11), 60-67.

Rusk, N., Resnick, M., Berg, R., \& Pezalla-Granlund, M. (2008). New pathways into robotics: Strategies for broadening participation. Journal of Science Education and Technology (17), 59 69.

Salomon, G. \& Perkins, D.N. (1987). Transfer of cognitive skills from programming: When and how? Journal of Educational Computing Research 3, 149-169.

Sesame Workshop. (2009). Sesame Workshop and The PNC Foundation Join White House Effort on STEM Education. Retrieved from http://www.sesameworkshop.org/newsandevents/pressreleases/stemeducation 11212009.

U.S. Congress Joint Economic Committee. (2012). STEM Education: Preparing for the Jobs of the Future. Washington, D.C. Retrieved from:

http://www.jec.senate.gov/public/index.cfm?a=Files.Serve\&File id=6aaa7e1f-9586-47be-82e7$\underline{326 f 47658320 .}$. 
U.S. Department of Education, Office of Educational Technology. (2010). National Education Technology Plan. Washington, D.C. Retrieved from http://www.ed.gov/technology/netp-2010.

Vygotsky, L.S. (1978). Mind in Society: The Development of Higher Psychological Processes. Cambridge, MA: Harvard University Press.

Wang, X.C., \& Ching, C.C. (2003). Social construction of computer experience in a first-grade classroom: Social processes and mediating artifacts. Early Education and Development, 14(3), $335-361$.

Wartella, E., \& Jennings, N. (2000). Children and computers: New technology - Old concerns. Children and Computer Technology, 10(2), 31-43.

White House. (2013). Educate to Innovate. Retrieved from http://www.whitehouse.gov/issues/education/educate-innovate.

Zigler, E.F., \& Bishop-Josef, S.J. (2006). The cognitive child vs. the whole child: Lessons form 40 years of Head Start. In Singer, D.G., Golinkoff, R.M., \& Hirsh-Pasek, K. (Eds.), Play = Learning: How play motivates and enhances children's cognitive and social-emotional growth (pp. 15 - 35). New York, NY: Oxford University Press.

Zillien, N., \& Hargittai, E. (2009). Digital Distinction: Status-specific internet uses. Social Science Quarterly. 90(2), 274-291.

(C) Copyright of Journal of Youth Development $~$ Bridging Research and Practice. Content may not be copied or emailed to multiple sites or posted to a listserv without copyright holder's express written permission. Contact Editor at: patricia.dawson@oregonstate.edu for details. However, users may print, download or email articles for individual use.

ISSN 2325-4009 (Print); ISSN 2325-4017 (Online) 